\title{
The potential interaction between clopidogrel and proton pump inhibitors: a systematic review
}

Joao Paulo de Aquino Lima', James M Brophy ${ }^{2 *}$

\begin{abstract}
Background: Recently, several publications have investigated a possible drug interaction between clopidogrel and proton pump inhibitors (PPIs), and regulatory agencies have issued warnings despite discordant study results. In an attempt to clarify the situation, we performed a systematic review with a critical analysis of study methodologies to determine whether varying study quality (that is, bias) could explain the discordant results.

Methods: A systematic review of all studies reporting clinical outcomes was performed using an electronic literature search of the MEDLINE and EMBASE databases, abstracts from the major cardiology conferences and a hand-search of bibliographies from identified articles. Each study was evaluated for its risk of bias according to a prespecified quality measure scale.

Results: A total of 18 studies were identified. Ten of 13 studies judged to be of low scientific quality reported a statistically positive interaction between clopidogrel and the general class of PPIs, and each concluded this was likely a clinically meaningful effect. None of the five studies judged to be of moderate or high quality reported a statistically significant association. Multiple sources of heterogeneity (that is, different populations, outcomes assessed, drug exposure methods and study quality) prevented a formal quantitative analysis of all studies. An increased risk of bias was observed in the positive studies, resulting in an inverse correlation between study quality and a reported statistically positive interaction $(10 / 13$ versus $0 / 5 ; P=p=0.007)$. There was also no clinical evidence for a positive interaction according to specific PPIs.

Conclusion: The observed association between clopidogrel and PPIs is found uniquely in studies judged to be of low quality and with an increased risk of bias. High-quality evidence supporting a clinically significant clopidogrel/ PPI interaction is presently lacking.
\end{abstract}

\section{Background}

Clopidogrel is a widely prescribed thienopyridine for the prevention of atherothrombotic complications following acute coronary syndromes (ACS) or percutaneous coronary interventions (PCIs) [1]. Clopidogrel is a prodrug that has no intrinsic antiplatelet activity without activation by hepatic metabolism through the cytochrome P450 (CYP) system [2]. Multiple CYP enzymes have been implicated in this process, but recently the CYP2C19 enzyme has assumed predominance as it is involved in both sequential oxidative steps [3]. The possibility of drug interactions limiting clopidogrel's efficacy was raised several years following in vitro statin and clopidogrel studies, but without definitive clinical

\footnotetext{
* Correspondence: james.brophy@mcgill.ca

2Department of Medicine, McGill University, Montreal, Quebec, Canada

Full list of author information is available at the end of the article
}

confirmation of increased adverse outcomes [4-6]. Recently, mechanistic in vitro studies have suggested that proton pump inhibitors (PPIs) may diminish clopidogrel's clinical efficacy via CYP2C19 competitive inhibition [7-10]. Consistent with these in vitro observations, several clinical studies have shown higher cardiovascular events in clopidogrel patients exposed to PPIs compared to those not exposed [11,12], leading the Food and Drug Administration (FDA) [13] and the European Medicines Agency [14] to issue public alerts recommending the avoidance of prescribing PPIs in patients who also take clopidogrel. However, as the studies have largely been nonexperimental, the possibility of a spurious association due to bias needs to be attentively considered.

This is a clinically important question as many cardiac patients are also at high risk of gastrointestinal (GI)

\section{C)


bleeding (due to age, smoking and concomitantly prescribed drugs), and PPIs may substantially mitigate this risk [15]. Previous reviews of this interaction question have appeared [16-20], but they have not (1) been systematic, (2) provided a critical analysis of methodological issues or (3) integrated these safety concerns with prior knowledge of clopidogrel's time frame of action. The present review addresses these issues by performing a systematic and critical analysis of all clinical studies of this putative interaction.

\section{Methods}

We reviewed the MEDLINE and EMBASE electronic databases from January 1, 2005, to October 7, 2010, without any language restriction, combining search terms for clopidogrel ("clopidogrel" OR "Plavix" OR "thienopyridine"), PPIs ("PPI" OR “ omeprazole" OR "lansoprazole" OR "pantoprazole" OR "esomeprazole" OR "rabeprazole") with those for cardiovascular outcomes ("mortality" OR "cardiovascular disease" OR "heart disease" OR "CAD" OR "MI" OR "UA" OR "coronary angiography" OR "coronary restenosis" OR "PCI" OR "stroke") and drug interaction ("interaction" OR " inhibition" OR " CYP2C19"). References of relevant identified articles were hand-searched for additional studies. Abstracts from medical organization conferences (American Heart Association, American College of Cardiology, European Society of Cardiology and Transcatheter Cardiovascular Therapeutics) were manually searched from 2005. A priori it was decided that only articles reporting clinical outcomes would be retained. Mechanistic in vitro studies measuring platelet aggregation were therefore excluded. Two investigators independently reviewed articles for inclusion and study quality. Both reviewers examined the methodology component independently of the study results, but given the publicity surrounding the individual studies it was impossible to ensure that the reviewers were totally blinded to the outcomes. It was planned to resolve disagreements by consensus, but there was perfect agreement between the investigators on their initial assessments. This systematic review was performed according to the PRISMA guidelines (see online Additional file 1).

Overall study quality was defined as high for well-performed randomized clinical trials (RCTs) as they exhibit the best internal validity. Observational studies are considered of lower quality as they have less internal validity due to numerous potential biases and consequently could attain a maximum moderate quality score. By following published guidelines to improve the reporting of observational studies [21] and specifically to mitigate against potential biases [22], we qualitatively evaluated all the observational studies for their propensity for the most common and important biases (selection, confounding and misclassification), thereby allowing their final classification into moderate- or low-quality levels. Overall observational study quality was judged to be moderate if the propensity for bias was low and specific methods to minimize bias were employed (explicit consideration of the time dependency of drug exposure and appropriate clinical outcome assessment to minimize misclassification, multiple methods to assess confounding and multivariate sensitivity analyses to test the independence and robustness of their results). Alternatively, studies were judged to be at moderate risk for bias and hence a low quality score.

The quality score of unpublished studies was systematically reduced by one grade owing to the absence of formal peer review. Isolated abstracts were considered to be of low quality as there are insufficient details to fully evaluate these reports. Finally, whenever possible, an external quality measure that compared survival curves from the clopidogrel efficacy randomized trials to the observational hazard ratios was performed to check for consistency in the etiologically relevant time windows.

Since study heterogeneity existed with respect to research methods, quality, study populations and health care systems, it was decided a priori that quantitative data pooling was inappropriate.

\section{Results}

Our literature search found 54 publications, and 18 of these studies [11,12,23-38] fulfilled our inclusion criteria (see Figure 1). One study was experimental with random PPI allocation [25], while the others were nonexperimental. Study details are presented in Table 1. Two studies $[12,36]$ with an otherwise low propensity for bias considered a primary endpoint of only nonfatal myocardial infarction (MI), ignoring fatal myocardial infarction, which has been a recurrent component of the composite measure of clopidogrel efficacy. Although an increased risk with the clopidogrel-PPI combination for nonfatal myocardial infarction was observed in both studies, mortality was actually lower in the PPI-exposed group in one study [12] and was not reported in the other [36], such that the more logical and standard combined endpoint of cardiovascular death and nonfatal MI could not be reliably evaluated. The lack of justification for their primary outcome and lack of sensitivity analyses regarding potential different adverse outcomes explains the lower assigned quality ratings for these two studies.

Among the full published studies judged to be methodologically weak, several potential biases (selection, residual confounding, immortal time and interpretative) were noted. Ten of 13 studies judged to be of low quality reported a statistically significant association for a harmful 


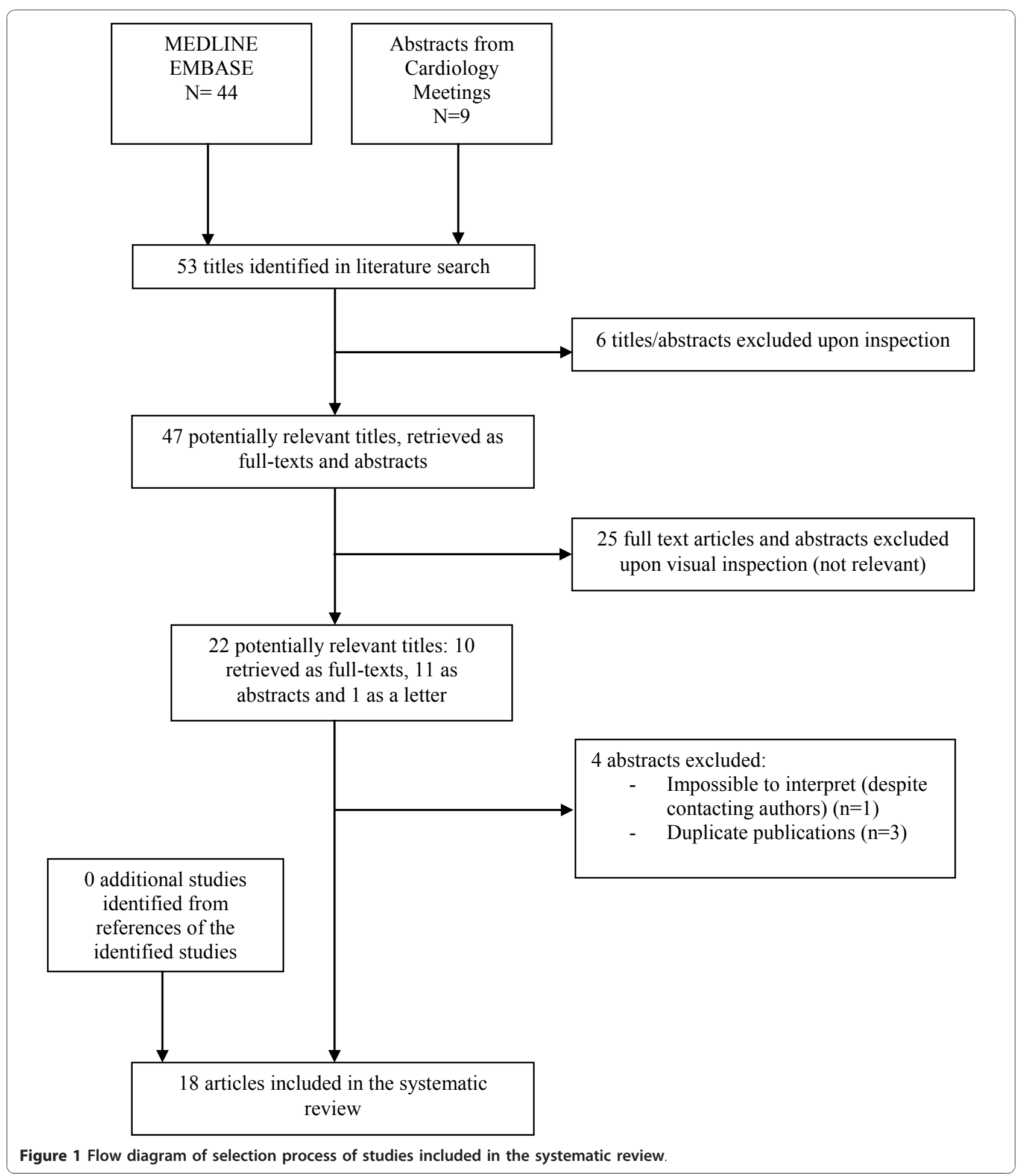

clopidogrel-PPI interaction, while none of the five moderate-quality studies found an association $(P=0.007)$.

Each individual study evaluated a combined exposure to any PPI for the assessment of their primary endpoint, with the exception of the experimental study [25], which was restricted to omeprazole. One study [12] did report a difference between pantoprazole and nonpantoprazole PPIs in their association with adverse clinical outcomes, but the corrected proper statistical analysis actually revealed no difference [39]. No other study demonstrated a clinically significant difference in clinical outcomes among the different PPIs. 
Table 1 Study detailsa

\begin{tabular}{|c|c|c|c|c|c|c|c|c|}
\hline Study & $\begin{array}{l}\text { Population } \\
\text { (special } \\
\text { conditions) }\end{array}$ & $\begin{array}{c}\text { PPIs } \\
\text { studied }\end{array}$ & $\begin{array}{l}\text { Propensity } \\
\text { for bias* }\end{array}$ & $\begin{array}{c}\text { Procedures } \\
\text { to } \\
\text { minimize } \\
\text { bias** }\end{array}$ & $\begin{array}{c}\text { Study } \\
\text { quality*** }\end{array}$ & $\begin{array}{l}\text { Primary } \\
\text { outcome/ } \\
\text { Results } \\
\text { (all PPIs } \\
\text { combined) } \\
\end{array}$ & $\begin{array}{l}\text { Secondary analyses } \\
\text { according to specific } \\
\text { PPIs }\end{array}$ & $\begin{array}{l}\text { Authors' conclusions } \\
\text { about clopidogrel-PPI } \\
\text { interaction }\end{array}$ \\
\hline Ho et al. [11] & $\begin{array}{l}\text { 8,205 ACS } \\
\text { (VA } \\
\text { patients) }\end{array}$ & $\begin{array}{c}\mathrm{L}, \mathrm{O}, \mathrm{P} \\
\mathrm{R}\end{array}$ & Moderate & Yes & Low & $\begin{array}{c}\text { 3-year mortality } \\
\text { or ACS } \\
\text { OR: } 1.25 ; 95 \% \mathrm{Cl}: \\
1.11-1.41\end{array}$ & $\begin{array}{l}\mathrm{O}=\mathrm{OR}: 1.24 ; 95 \% \mathrm{Cl}: \\
1.08-1.41 \\
\mathrm{R}=\mathrm{OR}, 2.83 ; 95 \% \mathrm{Cl}: \\
1.96-4.09 \\
L \mathrm{NR} \\
P \text { NR }\end{array}$ & $\begin{array}{l}\text { "Concomitant use after } \\
\text { hospital discharge for } \\
\text { ACS was associated } \\
\text { with increased risk of } \\
\text { adverse outcomes." }\end{array}$ \\
\hline $\begin{array}{c}\text { Juurlink et al. } \\
\text { [12] }\end{array}$ & $\begin{array}{l}13,636 \text { ACS } \\
\text { (age } \geq 66 \text { ) }\end{array}$ & $\begin{array}{c}\mathrm{L}, \mathrm{O}, \mathrm{P} \\
\mathrm{R}\end{array}$ & Moderate & Yes & Low & $\begin{array}{c}\text { 90-day nonfatal } \\
\text { Ml } \\
\text { OR: } 1.27 ; 95 \% \mathrm{Cl}: \\
1.03-1.57\end{array}$ & $\begin{array}{l}\mathrm{P}=\mathrm{OR} 1.02,95 \% \mathrm{Cl} \\
0.70-1.47 \\
\text { Non } \mathrm{P}=\mathrm{OR} 1.40(1.10- \\
1.77)\end{array}$ & $\begin{array}{l}\text { "Concomitant therapy } \\
\text { with PPIs other than } \\
\text { pantoprazole was } \\
\text { associated with loss of } \\
\text { beneficial effects of } \\
\text { clopidogrel." }\end{array}$ \\
\hline $\begin{array}{c}\text { Aubert et al. } \\
{[23]}\end{array}$ & $14,383 \mathrm{PCl}$ & NR & Uncertain & Uncertain & Low & $\begin{array}{c}\text { 1-year combined } \\
\text { stroke, Ml, } \\
\text { angina or CABG } \\
\text { OR:1.79; } 95 \% \mathrm{Cl} \\
1.62-1.97\end{array}$ & NR & $\begin{array}{l}\text { "The drug interaction } \\
\text { between PPIs and } \\
\text { clopidogrel may result } \\
\text { in serious adverse } \\
\text { outcomes within one } \\
\text { year of therapy } \\
\text { initiation." }\end{array}$ \\
\hline $\begin{array}{c}\text { Banerjee et } \\
\text { al. [24] }\end{array}$ & $534 \mathrm{PCl}$ & NR & Uncertain & Uncertain & Low & $\begin{array}{l}\text { Mortality, Ml, } \\
\quad \text { repeat } \\
\text { revascularization } \\
\text { and stroke } \\
\text { OR } 1.54 \text { no Cl } P \\
\quad<0.006 \\
\text { (557-615 days) }\end{array}$ & NR & $\begin{array}{l}\text { "PPI(s) with clopidogrel } \\
\text { is associated with an } \\
\text { increased risk." }\end{array}$ \\
\hline $\begin{array}{c}\text { Bhatt et al. } \\
\text { [25] }\end{array}$ & $\begin{array}{l}3,267 \text { ACS } \\
\text { PCI }\end{array}$ & $\mathrm{O}$ & Low & Yes & High & $\begin{array}{l}\text { 130-day CD, } \\
\text { nonfatal Ml, } \\
\text { revascularization } \\
\text { or ischemic } \\
\quad \text { stroke } \\
\text { HR: } 1.02 ; 95 \% \mathrm{Cl} \\
\quad=0.70-1.51\end{array}$ & Only O studied & $\begin{array}{l}\text { "No apparent } \\
\text { cardiovascular } \\
\text { interaction between } \\
\text { clopidogrel and } \\
\text { omeprazole" }\end{array}$ \\
\hline $\begin{array}{c}\text { Dunn et al. } \\
\text { [26] }\end{array}$ & $1,053 \mathrm{PCl}$ & NR & Uncertain & No & Low & $\begin{array}{l}\text { 1-year death, Ml } \\
\text { or stroke } \\
\text { OR: } 1.63 ; 95 \% \mathrm{Cl} \text {, } \\
1.02-2.62\end{array}$ & NR & $\begin{array}{l}\text { "PPI use was } \\
\text { associated with an } \\
\text { increased } \\
\text { cardiovascular risk." }\end{array}$ \\
\hline $\begin{array}{c}\text { Gaspar et al. } \\
{[27]}\end{array}$ & 922 ACS & $O, L, R$ & Uncertain & Uncertain & Low & $\begin{array}{l}\text { 6-month death, } \\
\text { Ml or UA } \\
\text { 8.8\% vs. } 8.4 \%, P \\
=\text { NS }\end{array}$ & NR & $\begin{array}{l}\text { "Was not associated } \\
\text { with a worse prognosis } \\
\text { in patients with ACS" }\end{array}$ \\
\hline $\begin{array}{c}\text { Gupta et al. } \\
{[28]}\end{array}$ & $\begin{array}{l}315 \mathrm{PCl} \\
\text { (VA } \\
\text { patients) }\end{array}$ & $L, O, R$ & Moderate & No & Low & $\begin{array}{c}\text { 4-year death, Ml } \\
\text { Or TVF } \\
\text { OR: } 1.95 ; 95 \% \mathrm{Cl}: \\
1.09-3.49\end{array}$ & $N R$ & $\begin{array}{l}\text { "PPIs may attenuate } \\
\text { clopidogrel's beneficial } \\
\text { antiplatelet effect." }\end{array}$ \\
\hline $\begin{array}{l}\text { Huang et al. } \\
\text { [29] }\end{array}$ & $\begin{array}{l}\text { 3,278 PCl } \\
\text { (Taiwan) }\end{array}$ & NR & Moderate & No & Low & $\begin{array}{c}\text { 5-year all-cause } \\
\text { mortality } \\
\text { HR: } 1.65 ; 95 \% \mathrm{Cl} \\
1.35-2.01\end{array}$ & NR & $\begin{array}{l}\text { "Concomitant use } \\
\text { should be done with } \\
\text { care to avoid adverse } \\
\text { outcomes." }\end{array}$ \\
\hline $\begin{array}{l}\text { O'Donoghue } \\
\text { et al. [30] }\end{array}$ & $\begin{array}{l}6,795 \text { ACS } \\
\text { (age } \geq 60 \text { ) }\end{array}$ & $\begin{array}{c}E, L, O \\
P, R\end{array}$ & Low & Yes & Moderate & $\begin{array}{l}\text { 1-year CD, Ml or } \\
\text { stroke } \\
\text { OR: } 0.94 ; 95 \% \mathrm{Cl} \text { : } \\
0.80-1.11\end{array}$ & $\begin{array}{l}\text { No specific data reported } \\
\text { "Regardless of PPI type } \\
\text { (including omeprazole } \\
\text { alone or the exclusion of } \\
\text { pantoprazole), no } \\
\text { independent association } \\
\text { existed" }\end{array}$ & $\begin{array}{l}\text { "No clinically relevant } \\
\text { adverse cardiovascular } \\
\text { interaction between } \\
\text { clopidogrel and PPIs." }\end{array}$ \\
\hline $\begin{array}{c}\text { Pezalla et al. } \\
\text { [31] }\end{array}$ & $\begin{array}{l}1,010 \text { ACS } \\
\text { (age <65) }\end{array}$ & NR & Uncertain & No & Low & $\begin{array}{c}\text { 1-year adjusted } \\
\text { Ml } \\
\text { OR 4.3; } 95 \% \mathrm{Cl} \\
2.2-8.4^{\#}\end{array}$ & NR & $\begin{array}{l}\text { "Evidence is pointing } \\
\text { toward a potentially } \\
\text { significant interaction." }\end{array}$ \\
\hline
\end{tabular}


Table 1: Study detailsa (Continued)

\begin{tabular}{|c|c|c|c|c|c|c|c|c|}
\hline $\begin{array}{c}\text { Ramirez et al. } \\
\text { [32] }\end{array}$ & $534 \mathrm{PCl}$ & NR & Uncertain & Uncertain & Low & $\begin{array}{c}\text { 1-year mortality/ } \\
\text { MI } \\
\text { OR NA } \\
P=0.32\end{array}$ & NR & $\begin{array}{l}\text { "Concomitant use of } \\
\text { PPI's did not result in } \\
\text { adverse cardiovascular } \\
\text { outcomes at one year." }\end{array}$ \\
\hline $\begin{array}{c}\text { Rassen et al. } \\
\text { [33] }\end{array}$ & $\begin{array}{l}18,565 \text { ACS } \\
\text { PCl } \\
\text { (age } \geq 65)\end{array}$ & $\begin{array}{c}E, L, O \\
P, R\end{array}$ & Low & Yes & Moderate & $\begin{array}{c}\text { 180-day death } \\
\text { or Ml } \\
\text { OR: 1.22; } 95 \% \mathrm{Cl} \text { : } \\
0.99-1.51\end{array}$ & $\begin{array}{l}O=R R 1.17 ; 95 \% \mathrm{Cl}: \\
0.68-2.01 \\
P=R R 1.26 ; 95 \% \mathrm{Cl}: \\
0.93-1.71\end{array}$ & $\begin{array}{l}\text { "We did not observe } \\
\text { conclusive evidence of } \\
\text { a clopidogrel/PPI } \\
\text { interaction." }\end{array}$ \\
\hline Ray et al. [34] & $\begin{array}{l}20,596 \text { ACS } \\
\mathrm{PCI} \\
\text { (age } \geq 30 \text { ) }\end{array}$ & $\begin{array}{c}E, L, O \\
P, R\end{array}$ & Low & Yes & Moderate & $\begin{array}{c}\text { 1-year } \mathrm{Ml}, \mathrm{CD} \text { or } \\
\text { stroke } \\
\text { HR: 0.99; } 95 \% \mathrm{Cl} \text {, } \\
0.82-1.19\end{array}$ & $\begin{array}{l}E=H R \quad 0.71 ; 95 \% \text { Cl 0.48- } \\
1.06 \\
L=H R \quad 1.06 ; 95 \% \text { Cl 0.77- } \\
1.45 \\
O=H R \quad 0.79 ; 95 \% \text { Cl 0.54- } \\
1.15 \\
P=H R \quad 1.08 ; 95 \% \text { Cl 0.88- } \\
1.32 \\
R=H R 0.54 ; 95 \% \text { Cl 0.30- } \\
0.97\end{array}$ & $\begin{array}{l}\text { "Concurrent use of a } \\
\text { PPI was not associated } \\
\text { with a statistically } \\
\text { significant increased } \\
\text { risk for serious } \\
\text { cardiovascular disease." }\end{array}$ \\
\hline $\begin{array}{l}\text { Sarafoff et al. } \\
\text { [35] }\end{array}$ & $2,025 \mathrm{PCl}$ & NR & Uncertain & Uncertain & Low & $\begin{array}{l}\text { 30-day stent } \\
\text { thrombosis } \\
\text { OR NR, } P= \\
0.002 \\
\text { death OR NR, } P \\
=0.04\end{array}$ & NR & $\begin{array}{l}\text { "A PPI is associated } \\
\text { with higher rates of } \\
\text { stent thrombosis and } \\
\text { an increased mortality." }\end{array}$ \\
\hline $\begin{array}{c}\text { Stockl et al. } \\
{[36]}\end{array}$ & $\begin{array}{l}2,066 \text { ACS } \\
\mathrm{PCl} \\
\text { (age 18-84) }\end{array}$ & $\begin{array}{c}E, L, O \\
P, R\end{array}$ & Moderate & Yes & Low & $\begin{array}{l}\text { 1-year nonfatal } \\
\quad \text { Ml } \\
\text { HR: 1.93; } 95 \% \text { Cl: } \\
\text { 1.05-3.54 }\end{array}$ & $\begin{array}{l}P=H R 2.18 ; 95 \% \mathrm{Cl} 0.88- \\
5.39\end{array}$ & $\begin{array}{l}\text { "Patients who received } \\
\text { clopidogrel plus a PPI } \\
\text { had a significantly } \\
\text { higher risk." }\end{array}$ \\
\hline $\begin{array}{l}\text { Tsiaousis et } \\
\text { al. [37] }\end{array}$ & $612 \mathrm{PCl}$ & NR & Uncertain & Uncertain & Low & $\begin{array}{c}\text { 1-year death HR: } \\
\text { 1.1; 95\% Cl: 0.7- } \\
1.4 \\
\text { 1-year Ml HR: } \\
\text { 1.0; 95\% Cl: 0.8- } \\
1.3\end{array}$ & NR & $\begin{array}{l}\text { "PPIs drug therapy } \\
\text { does not have any } \\
\text { impact on the } \\
\text { effectiveness." }\end{array}$ \\
\hline $\begin{array}{c}\text { Charlot et al. } \\
\text { [38] }\end{array}$ & 56,408 AMI & $\begin{array}{c}E_{1} L, O \\
P\end{array}$ & Low & Yes & Moderate & $\begin{array}{c}\text { 1-year death, Ml, } \\
\text { stroke } \\
\text { HR: 0.98; } 95 \% \mathrm{Cl} \text {, } \\
0.88-1.10\end{array}$ & $\begin{array}{l}\text { "No difference in risk } \\
\text { associated with the type } \\
\text { of PPI" }\end{array}$ & $\begin{array}{l}\text { "No statistically } \\
\text { significant interaction } \\
\text { occurred between a } \\
\text { PPI and clopidogrel." }\end{array}$ \\
\hline
\end{tabular}

${ }^{\mathrm{a} A C S}$, acute coronary syndrome; $\mathrm{AMI}$, acute myocardial infarction; $\mathrm{AR}$, absolute risk; $\mathrm{C}$, clopidogrel; $\mathrm{CABG}$, coronary artery bypass graft; $\mathrm{CD}$, cardiovascular death; $\mathrm{Cl}$, confidence interval; HR, hazard ratio; $\mathrm{Ml}$, myocardial infarction; OHIP, Ontario health insurance program; OR, odds ratio; $\mathrm{PCl}$, percutaneous coronary intervention; PPI, proton pump inhibitor; TIA, transient ischemic attack; TVF, target vessel failure; TVR, target vessel revascularization; VA, Veterans Administration; $\mathrm{UA}$, unstable angina; NR, not reported; $\mathrm{E}$, esomeprazole; $\mathrm{L}$, lansoprazole; $\mathrm{O}$, omeprazole; $\mathrm{P}$, pantaprazole; $\mathrm{R}$, rabeprazole.

*Biases considered are selection, confounding and misclassification; the probability of bias in the studies available as abstracts was deemed uncertain. **Procedures to minimize bias include multiple sensitivity analyses for varying drug exposures, multiple methods for control of confounding and time-varying analysis for misclassification.

***High study quality was reserved for RCTs. For observational studies, moderate study quality required low propensity for bias and specific efforts to minimize bias. Otherwise, quality was assessed as low.

${ }^{\#}$ Calculated by combining high- and low-dose PPI groups.

\section{Discussion}

Our systematic review identified 18 clinical studies of a clopidogrel-PPI interaction, with the majority (10) reporting a statistically significant result. Multiple sources of heterogeneity (different populations, outcomes assessed, drug exposure methods and study quality) existed between the studies, preventing a formal quantitative analysis of all studies. However, a stratified analysis based on study quality demonstrated an inverse correlation between study quality and a positive outcome. Moreover, none of the 18 studies found a clinically meaningful difference between the various PPIs. Therefore, high-quality evidence supporting a clinically significant clopidogrel-PPI interaction is presently lacking. Consequently, while good prescribing patterns are to be endorsed for all medications, recent edicts to avoid PPIs in cardiac patients with a clinical indication for their use seem poorly justified.

While our criteria for judging study quality are standardized and were applied a priori and independently of the study results, their validity would be enhanced by some empirical assessment. Certainly, these quality criteria have face and content validity. In judging the presence of construct validity, it may be helpful to review what is known about clopidogrel efficacy from highquality clinical trials. The Clopidogrel in Unstable 
Angina to Prevent Recurrent Events Trial (or CURE) was the seminal randomized trial [1] showing the benefits of clopidogrel in acute coronary syndromes, namely, a $1.9 \%$ absolute reduction in the primary endpoint of cardiovascular death, nonfatal MI or stroke with clopidogrel which was evident by 3 months with no or very little additional advantage at later time points (see Figure 2). In a PCI trial [40], clopidogrel again was shown to exhibit its beneficial results principally in the first 30 90 days. A lack of long-term benefit in the non-acute setting was confirmed in the randomized CHARISMA trial [41], which showed no advantages in stable cardiac or high-risk patients at any time over a 28 -month follow-up period. Contrast these results with those from the observational studies of the putative drug interaction attributing 9\% [11] and 18\% [28] absolute increases in adverse outcomes to the inhibition of the protective effects of clopidogrel. Another study [29] attributed a greater than $15 \%$ absolute difference in all-cause mortality to this putative association. This represents a manyfold larger effect than the observed clopidogrel benefits in randomized trials. Moreover, in these studies, no significant difference was seen between the clopidogrel-PPI group and the clopidogrel-alone group within the therapeutically active 30-to 90-day window (see Figure 2). The observed adverse effects attributed to the drug interaction were therefore occurring at a time when clopidogrel has not been shown to be therapeutically active. It therefore seems likely that the observed differences between PPI users and nonusers are unrelated to

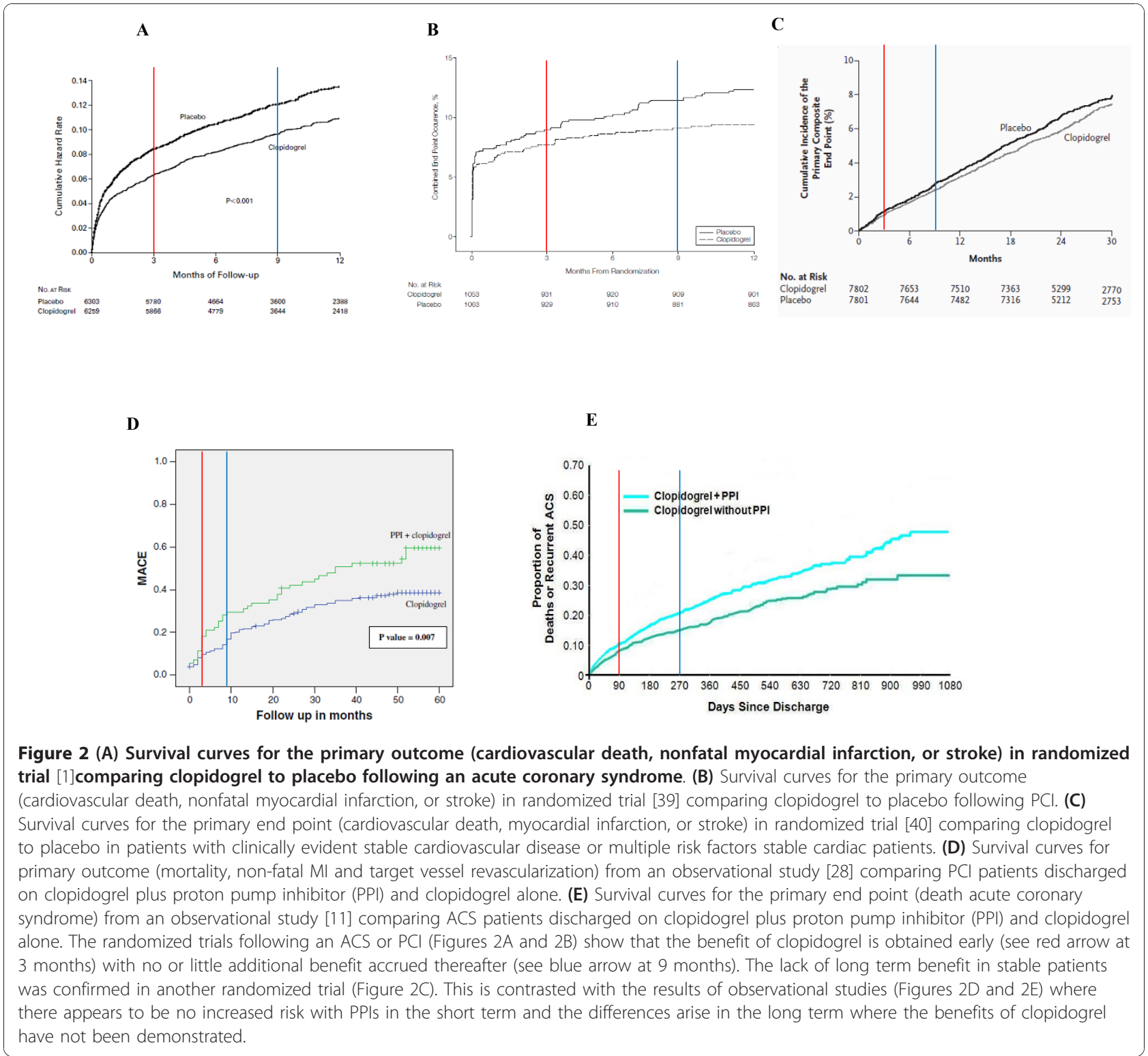


clopidogrel inhibition, but rather are related to residual confounding from unmeasured prognostic variables as measured baseline prognostic factors were markedly different between the groups. Supporting this hypothesis, a post hoc analysis of the CREDO study [26] showed a $2 \%$ absolute increase in adverse cardiac events even among placebo patients who were exposed to PPIs. Unfortunately, the other observational studies have not presented survival functions, so a similar evaluation of the biological plausibility and consistency of their results cannot be made.

It bears repeating that the only high-quality randomized trial permitting an unconfounded assessment of a causal association [25] did not show any evidence of harm. Moreover, it may be argued that post hoc analyses of clinical trial data offer better internal validity than other observational studies because of a greater homogeneity in the patient population, increased and higherquality baseline clinical data and better outcome validation, thereby potentially mitigating, but certainly not eliminating, possible biases [22]. Our evaluation of the present studies empirically confirmed this association, with the post hoc clinical trial [30] receiving a higher score by our independent criteria providing further external support of our quality scale. Again, this higherquality study did not show evidence for the putative interaction.

Our systematic review provides a reproducible, prespecified and comprehensive review of the totality of the evidence in the literature of a potential interaction between clopidogrel and PPIs, thereby facilitating informed decision making. However, our systematic review may be criticized for our inability to ensure total blinding of methodological assessment from outcomes. As with any systematic review, we are also limited by the quality of the original publications. While we found a paucity of high-quality clinical evidence to support a clopidogrelPPI interaction either collectively or individually, the power to find such an association is limited and does not preclude the possibility that later high-quality studies may appear to confirm this putative drug association.

The issue of adverse outcomes associated with concomitant use of clopidogrel and PPIs has been assessed in previous reviews [16-20], as well as by American and European regulatory agencies $[13,14]$, which concluded that the interaction is clinically significant. However, previous reviews have been dominated by studies with surrogate laboratory endpoints, were not systematic in identifying the clinical evidence, did not consider the putative interaction effect as a function of our previous knowledge of clopidogrel efficacy and did not provide a critical analysis of the methodological issues of each study. Lower-quality observational studies tend to overestimate effect size because of bias [42]. In the case of regulatory agencies, the threshold to report putative clinical adverse effects is naturally low in an effort to protect public health. However, with the recent spate of controversies regarding the cardiovascular safety of approved drugs such as rofecoxib and rosiglitazone, there is perhaps a strong desire for these agencies to avoid appearing inactive and rather to be perceived as proactive. Nevertheless, it is disconcerting that the potential positive benefits of avoiding gastrointestinal bleeds in high-risk patients appear to have been minimized if not ignored and that regulatory decisions have been made not on a systematic assessment of the clinical evidence, but rather largely on surrogate laboratory data and isolated clinical studies of questionable validity. One regulatory agency [14] has targeted specific PPIs as being culpable without a single valid clinical study to support this claim. Correctly or not, the impression is that the safety of the regulatory agencies from criticism has become more important than the critical assessment of public health safety.

Beyond our specific conclusion that the evidence for a clinically meaningful clopidogrel-PPI interaction is poor, our critical analysis of this potential drug interaction leads to several general observations regarding pharmacoepidemiological research and subsequent policy decisions. First, selection bias or confounding by indication remains a potential threat to all observational research of both intended and unintended effects. Second, residual confounding is likely to be persistent when multivariate analysis is limited to data routinely collected from purely administrative data sets lacking the necessary clinical granularity. Post hoc analyses of randomized trials are similarly subject to the same potential biases, but the magnitude may be less owing to both a more homogeneous source population (from the strict inclusion and exclusion criteria, which favor the recruitment of populations with only one major health issue), the availability of more extensive baseline clinical data (decreasing residual confounding) and more systematic outcome assessment through adjudication (decreasing misclassification or information bias), thereby allowing a more rigorous assessment of the independent contribution of any putative association. Third, studies of surrogate endpoints (for example, platelet inhibition) may provide interesting avenues for future outcomes research, but these studies should not be used for clinical and regulatory decision making. The perils of surrogate markers have been repeatedly demonstrated in cardiovascular medicine, with specious examples ranging from ventricular ectopy suppression to lowering of glycosylated hemoglobin. Fourth, when possible, cohort studies should present survival functions, which may help in determining the reasonableness of conclusions by ensuring that events occur within the etiologically 
relevant time windows as demonstrated by RCTs. Finally, the time-varying nature of drug exposure must be meticulously tracked and sensitivity analyses must be performed to assess the robustness of conclusions to residual confounding or measurement error.

Readers should reasonably expect that the peer review process provides some guidance and discussion about potential biases in observational research. Too often there is a tendency to explain discordant study results not by considering biases, but by assuming that the results are due to different populations, interventions or outcomes $[43,44]$. In our opinion, the probability of such effect modification is often small compared to the probability of bias. While some biases are subtle, others become more obvious with attentive reading and consideration of the totality of the evidence. The need to improve the reliability and value of medical research has been well recognized by many groups [43-45], and several guidelines have been published [21,22], including those that pertain to observational research, but more specific guidelines for designing and interpreting pharmacoepidemiological studies may be helpful.

\section{Conclusions}

This systematic review of the putative drug interaction between clopidogrel and PPIs identified 18 clinical studies. Rigorous and extensive evaluation of the study methodologies demonstrated that the majority were of low quality, and only these studies reported a positive association between clopidogrel-PPI exposure and increased cardiovascular events. Supporting the notion that bias may be responsible for a spurious association, the increase in cardiovascular events attributed to this interaction appears to be occurring within a therapeutic window when clopidogrel has not been shown to be etiologically active. Conversely, all studies assessed as high quality did not demonstrate this association. No study was able to isolate any individual PPI as being more prone to adverse cardiac outcomes. Careful attention to the methodological details of published studies is therefore mandatory to avoid reaching questionable scientific conclusions. In light of this systematic review, and given the potential benefit of PPIs for patients at high risk of gastrointestinal bleeding, regulatory agencies may wish to reevaluate their recent edicts regarding this putative interaction.

\section{Additional material}

Additional file 1: PRISMA Checklist. This file is recommended to be included in all systematic review. The checklist enables the reader to rapidly identify where the key elements required in a high-quality systematic review are found.

\section{Acknowledgements}

This work did not benefit from any external funding. Dr Brophy is a funded research scientist of Le Fonds de la Recherche en Santé du Québec.

\section{Author details}

${ }^{1}$ Federal University of Ceará School of Medicine, Fortaleza, Brazil.

2Department of Medicine, McGill University, Montreal, Quebec, Canada.

\section{Authors' contributions}

$\mathrm{JMB}$ conceived the project. JMB and JPAL developed the protocol jointly and independently abstracted the data. JMB did the statistical analysis. JMB and JPAL jointly wrote all drafts and the final manuscript.

\section{Competing interests}

The authors declare that they have no competing interests.

Received: 23 September 2010 Accepted: 6 December 2010

Published: 6 December 2010

\section{References}

1. Yusuf S, Zhao F, Mehta SR, Chrolavicius S, Tognoni G, Fox KK, Clopidogrel in Unstable Angina to Prevent Recurrent Events Trial Investigators: Effects of clopidogrel in addition to aspirin in patients with acute coronary syndromes without ST-segment elevation. N Engl J Med 2001, 345:494-502.

2. Savi P, Herbert JM, Pflieger AM, Dol F, Delebassee D, Combalbert J, Defreyn G, Maffrand JP: Importance of hepatic metabolism in the antiaggregating activity of the thienopyridine clopidogrel. Biochem Pharmacol 1992, 44:527-532.

3. Steinhub/ SR: Genotyping, clopidogrel metabolism, and the search for the therapeutic window of thienopyridines. Circulation 2010, 121:481-483.

4. Lau WC, Waskell LA, Watkins PB, Neer CJ, Horowitz K, Hopp AS, Tait AR, Carville DG, Guyer KE, Bates ER: Atorvastatin reduces the ability of clopidogrel to inhibit platelet aggregation: a new drug-drug interaction. Circulation 2003, 107:32-37.

5. Martin PT, Denman R: Atorvastatin-clopidogrel interaction. Circulation 2003, 107:e223.

6. Mitsios JV, Papathanasiou Al, Rodis Fl, Elisaf M, Goudevenos JA, Tselepis AD: Atorvastatin does not affect the antiplatelet potency of clopidogrel when it is administered concomitantly for 5 weeks in patients with acute coronary syndromes. Circulation 2004, 109:1335-1338.

7. Cuisset T, Frere C, Quilici J, Poyet R, Gaborit B, Bali L, Brissy O, Morange PE, Alessi MC, Bonnet JL: Comparison of omeprazole and pantoprazole influence on a high 150-mg clopidogrel maintenance dose the PACA (Proton Pump Inhibitors And Clopidogrel Association) prospective randomized study. J Am Coll Cardiol 2009, 54:1149-1153.

8. Gilard M, Arnaud B, Cornily JC, Le GG, Lacut K, Le CG, Mansourati J, Mottier D, Abgrall JF, Boschat J: Influence of omeprazole on the antiplatelet action of clopidogrel associated with aspirin: the randomized, double-blind OCLA (Omeprazole CLopidogrel Aspirin) study. J Am Coll Cardiol 2008, 51:256-260.

9. Siller-Matula JM, Spiel AO, Lang IM, Kreiner G, Christ G, Jilma B: Effects of pantoprazole and esomeprazole on platelet inhibition by clopidogrel. Am Heart J 2009, 157:148, e1-e5.

10. Small DS, Farid NA, Payne CD, Weerakkody GJ, Li YG, Brandt JT, Salazar DE, Winters KJ: Effects of the proton pump inhibitor lansoprazole on the pharmacokinetics and pharmacodynamics of prasugrel and clopidogrel. J Clin Pharmacol 2008, 48:475-484.

11. Ho PM, Maddox TM, Wang L, Finn SD, Jesse RL, Peterson ED, Rumsfeld JS: Risk of adverse outcomes associated with concomitant use of clopidogrel and proton pump inhibitors following acute coronary syndrome. JAMA 2009, 301:937-944

12. Juurlink DN, Gomes T, Ko DT, Szmitko PE, Austin PC, Tu JV, Henry DA, Kopp A, Mamdani MM: A population-based study of the drug interaction between proton pump inhibitors and clopidogrel. CMAJ 2009, 180:713-718.

13. Food and Drug Adminstration: Information for Healthcare Professionals: Update to the labeling of Clopidogrel Bisulfate (marketed as Plavix) to alert healthcare professionals about a drug interaction with omeprazole 
(marketed as Prilosec and Prilosec OTC). 2009 [http://www.fda.gov/Drugs/ DrugSafety/PostmarketDrugSafetylnformationforPatientsandProviders/ DrugSafetylnformationforHeathcareProfessionals/ucm 190787.htm], (accessed Nov 1 2010).

14. European Medicines Agency: Interaction between clopidogrel and proton-pump inhibitors. 2010 [http:/www.ema.europa.eu/humandocs/ PDFs/EPAR/Plavix/17494810en.pdf], (accessed June 15 2010).

15. Bhatt DL, Scheiman J, Abraham NS, Antman EM, Chan FK, Furberg CD, Johnson DA, Mahaffey KW, Quigley EM, Harrington RA, Bates ER, Bridges CR, Eisenberg MJ, Ferrari VA, Hlatky MA, Kaul S, Lindner JR, Moliterno DJ, Mukherjee D, Schofield RS, Rosenson RS, Stein JH, Weitz HH, Wesley DJ: ACCF/ACG/AHA 2008 expert consensus document on reducing the gastrointestinal risks of antiplatelet therapy and NSAID use. Am J Gastroenterol 2008, 103:2890-2907.

16. Chow CK, Moayyedi P, Devereaux PJ: Is it safe to use a proton pump inhibitor with clopidogrel? Pol Arch Med Wewn 2009, 119:564-568.

17. Juhasz M, Herszenyi L, Tulassay Z: Current standings of the proton pump inhibitor and clopidogrel co-therapy: review on an evolving field with the eyes of the gastroenterologist. Digestion 2010, 81:10-15.

18. Juurlink DN: Proton pump inhibitors and clopidogrel: putting the interaction in perspective. Circulation 2009, 120:2310-2312.

19. Norgard NB, Mathews KD, Wall GC: Drug-drug interaction between clopidogrel and the proton pump inhibitors. Ann Pharmacother 2009, 43:1266-1274.

20. Zarowitz BJ: Clopidogrel: with or without a proton pump inhibitor? Geriatr Nurs 2009, 30:188-192.

21. Von Elm E, Altman DG, Egger M, Pocock SJ, Gøtzsche PC Vandenbroucke JP, STROBE Initiative: The Strengthening the Reporting of Observational Studies in Epidemiology (STROBE) statement: guidelines for reporting observational studies. Lancet 2007, 370:1453-1457.

22. Cox E, Martin BC, Van ST, Garbe E, Siebert U, Johnson ML: Good Research Practices for Comparative Effectiveness Research: Approaches to Mitigate Bias and Confounding in the Design of Nonrandomized Studies of Treatment Effects Using Secondary Data Sources: The International Society for Pharmacoeconomics and Outcomes Research Good Research Practices for Retrospective Database Analysis Task Force Report-Part II. Value Health 2009.

23. Aubert RE, Epstein RS, Teagarden JR, Xia F, Yao J, Desta Z, Skaar T, Flockhart DA: Proton pump inhibitors effect on clopidogrel effectiveness: the Clopidogrel Medco Outcomes Study. Circulation 2008, 118:S815.

24. Banerjee S, Varghese C, Weideman R, Weideman M, Little BB: Proton pump inhibitors increase the risk of major adverse cardiovascular events in post-PCl patients who are on clopidogrel (Abstract P653). Eur Heart J 2009, 30(Suppl):92.

25. Bhatt DL, Cryer BL, Contant CF, Cohen M, Lanas A, Schnitzer TJ, Shook TL, Lapuerta P, Goldsmith MA, Laine L, Scirica BM, Murphy SA, Cannon CP: Clopidogrel with or without omeprazole in coronary artery disease. $\mathrm{N}$ Engl I Med 2010

26. Dunn SP, Macaulay TE, Brennan DM, Campbell CL, Charnigo RJ, Smyth SS, Berger PB, Steinhubl SR, Topol EJ: Baseline proton pump inhibitor use is associated with increased cardiovascular events with and without the use of clopidogrel in the CREDO Trial. Circulation 2008, 118:S815, (Abstract 3999).

27. Gaspar A, Ribeiro S, Naibas $S$, et al: Proton pump inhibitors in patients treated with aspirin and clopidogrel (Abstract P2679). Eur Heart J 2009, 30(Suppl):444.

28. Gupta E, Bansal D, Sotos J, Olden K: Risk of adverse clinical outcomes with concomitant use of clopidogrel and proton pump inhibitors following percutaneous coronary intervention. Dig Dis Sci 2010, 55:1964-1968.

29. Huang CC, Chen YC, Leu HB, Chen TJ, Lin SJ, Chan WL, Chen JW: Risk of adverse outcomes in Taiwan associated with concomitant use of clopidogrel and proton pump inhibitors in patients who received percutaneous coronary intervention. Am J Cardiol 2010, 105:1705-1709.

30. O’Donoghue ML, Braunwald E, Antman EM, Murphy SA, Bates ER, Rozenman Y, Michelson AD, Hautvast RW, Ver Lee PN, Close SL, Shen L, Mega IL, Sabatine MS, Wiviott SD: Pharmacodynamic effect and clinical efficacy of clopidogrel and prasugrel with or without a proton-pump inhibitor: an analysis of two randomised trials. Lancet 2009, 374:989-997.

31. Pezalla E, Day D, Pulliadath I: Initial assessment of clinical impact of a drug interaction between clopidogrel and proton pump inhibitors. J Am Coll Cardiol 2008, 52:1038-1039
32. Ramirez JF, Selzer F, Chakaprani R, et al: Proton pump inhibitor and clopidogrel combination is not associated with adverse clinical outcomes after PCl: the NHLBI dynamic registry. J Am Coll Cardiol 2009, 53(Suppl 1):A27.

33. Rassen JA, Choudhry NK, Avorn J, Schneeweiss S: Cardiovascular outcomes and mortality in patients using clopidogrel with proton pump inhibitors after percutaneous coronary intervention or acute coronary syndrome. Circulation 2009, 120:2322-2329.

34. Ray WA, Murray KT, Griffin MR, Chung CP, Smalley WE, Hall K, Daugherty JR, Kaltenbach LA, Stein CM: Outcomes with concurrent use of clopidogrel and proton-pump inhibitors: a cohort study. Ann Intern Med 2010, 152:337-345.

35. Sarafoff N, Sibbing D, Sonntag U, Schulz S, Schoemig A, Kastrati A: Higher stent thrombosis rate after coronary stenting in patients on dual antiplatelet treatment and concomitant treatment with proton pump inhibitors (abstr). Eur Heart J 2009, 30(Suppl):150.

36. Stockl KM, Le L, Zakharyan A, Harada AS, Solow BK, Addiego JE, Ramsey S: Risk of rehospitalization for patients using clopidogrel with a proton pump inhibitor. Arch Intern Med 2010, 170:704-710.

37. Tsiaousis GZ, Zairis MN, Patsourakos N, et al: Oral proton pump inhibitors and their impact on the effectiveness of dual anti-platelet therapy during the first year after elective coronary stenting (abstr). J Am Coll Cardiol 2009, 53(Suppl A):A335.

38. Charlot M, Ahlehoff $\mathrm{O}$, Norgaard ML, Jorgensen $\mathrm{CH}$, Sorensen $\mathrm{R}$, Abildstrom SZ, Hansen PR, Madsen JK, Kober L, Torp-Pedersen C, Gislason G: Proton-pump inhibitors are associated with increased cardiovascular risk independent of clopidogrel use: a nationwide cohort study. Ann Intern Med 2010, 153:378-386.

39. Allen MJ, McLean-Veysey P: Interaction between clopidogrel and proton pump inhibitors. CMAJ 2009, 180:1228-1229.

40. Steinhubl SR, Berger PB, Mann JT III, Fry ET, DeLago A, Wilmer C, Topol EJ: Early and sustained dual oral antiplatelet therapy following percutaneous coronary intervention: a randomized controlled trial. JAMA 2002, 288:2411-2420.

41. Bhatt DL, Fox KA, Hacke W, Berger PB, Black HR, Boden WE, Cacoub P, Cohen EA, Creager MA, Easton JD, Flather MD, Haffner SM, Hamm CW, Hankey GJ, Johnston SC, Mak KH, Mas JL, Montalescot G, Pearson TA, Steg PG, Steinhubl SR, Weber MA, Brennan DM, Fabry-Ribaudo L, Booth J, Topol EJ, CHARISMA Investigators: Clopidogrel and aspirin versus aspirin alone for the prevention of atherothrombotic events. N Engl J Med 2006, 354:1706-1717.

42. Suissa S: Immortal time bias in pharmaco-epidemiology. Am J Epidemiol 2008, 167:492-499

43. Altman DG: The scandal of poor medical research. BMJ 1994, 308:283-284.

44. Anonymous: Editorial: Are medical journals getting better-or worse? Lancet 2009, 374:950.

45. EQUATOR: [http://www.equator-network.org/home/], Accessed June 15, 2010.

\section{Pre-publication history}

The pre-publication history for this paper can be accessed here: http://www.biomedcentral.com/1741-7015/8/81/prepub

\section{doi:10.1186/1741-7015-8-81}

Cite this article as: Lima and Brophy: The potential interaction between clopidogrel and proton pump inhibitors: a systematic review. BMC Medicine 2010 8:81. 